\title{
Growth Performance and Health Status of Broiler Chickens Treated with Natural Kaolin
}

\author{
Somayia ElHag', Ali Abdel Motelib ${ }^{1}$, Mosaad A. Soltan ${ }^{2 *}$ and Mohamed Abdel Gawad ${ }^{1}$

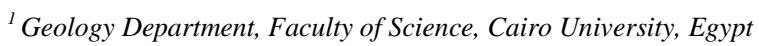 \\ ${ }^{2}$ Nutrition and Veterinary Clinical Nutrition Department, Faculty of Veterinary Medicine, Alexandria University, Egypt \\ *Corresponding author's Email: soltanmosaad@yahoo.com; (D) orciD: 0000-0002-7710-5631
}

\begin{abstract}
The use of Kaolin as an inert ingredient in feed has been very common in the poultry industry. The present study aimed to investigate the effects of different inclusion rates of Egyptian kaolinite in broiler chickens' diet on growth performance, immune response, some blood serum changes, and bone development. A total of 240 unsexed one-dayold Avian 48 breed chickens were used in this experiment. The chickens were individually weighed and randomly allotted into 3 equal groups (80 chickens per each group) and each group was subdivided into 4 replicates (20 chickens per replicate), which received one of the three experimental diets $(0.0,0.5$, and $1.0 \%$ kaolin for groups 1,2 , and 3, respectively) during the experimental period (6 weeks). The obtained data revealed that kaolin addition at the dose of 0.5 or $1.0 \%$ in broiler chickens' diet insignificantly increased final body weight by $4.5 \%$ and $4.4 \%$, respectively. On the other hand, it respectively decreased total feed intake by $1.0 \%$ and $1.8 \%$ and significantly improved the average feed conversion ratio and efficiency of energy utilization throughout the whole experimental period compared to the control. Moreover, kaolin addition had no adverse effect on the serum lipid profile and improved antioxidative activity through reduced nitric oxide and lipid peroxidase (malondialdehyde) concentrations or increased the activities of Glutathione peroxide, Catalase, and Superoxide dismutases in serum or liver tissues. Lysosomal and bactericidal activities were increased with kaolin addition at both levels in the broiler chickens' diets. The present results suggested that the broiler chickens' fed with kaolin-enriched diets improved growth, antioxidant activity, bone mineralization, and immune response.
\end{abstract}

Keywords: Antioxidant activity, Broiler chicken, Growth performance, Kaolin, Silicification, Strength

\section{INTRODUCTION}

Presently, general knowledge reveals that feed constitutes the highest and the most expensive input in any livestock especially poultry farms (Owen et al., 2010). Any major reduction or decrease in the cost of feed will extensively reduce the overall cost of production and increase the profit margin of the farm. In general, antibiotics are used in poultry feed to control infectious diseases, but they lead to drug resistance of microbes, which has led to many human health and environmental problems (Castanon, 2007).

As an additive, the natural clays have become a new line of an alternative to antibiotics and chemotherapeutics in the effective prevention of diseases (Ghosal, 1990). Clay minerals are mainly defined as hydrous layer aluminosilicates and it has some unique properties, which includes the high cation exchange capacities, the catalytic properties, and the plastic behavior when getting moist. Structures of clay minerals are mainly formed from a tetrahedral and octahedral sheet when they are combined into groups, and can be differentiated by the kinds of isomorphic action substitution (Moore and Reynolds, 1997). In systematic mineralogy, the kaolin known as a thin clay was white in color and was created by the weathering of aluminous minerals, such as feldspar, a plastic clay mineral. It was classified as a phyllosilicate group because of its absorption capacity and the absence of primary toxicity (Owen et al., 2012). Mechanical erosion created the rock under the tropical climate and at the increased temperatures and the chemical corrosion happened under the activity of water saturated with $\mathrm{CO}_{2}$ and humic acids which eluted from water (Bernard and Rost, 1992; Slivka, 2002). Kaolinite is a clay mineral with the chemical composition of $\mathrm{Al}_{2} \mathrm{Si}_{2} \mathrm{O}_{5}(\mathrm{OH})_{4}$. It has a low cation exchange capacity and usually absorbs water and forms a plastic, paste-like substance (Duda et al., 1990; Trckova et al., 2004). Kaolin as an inert ingredient has been used in poultry diets for the improvement of growth performance and alleviation of the adverse effects of mycotoxins (Safaeikatouli et al., 2011).

The current substance was used to promote the reduction of toxins that cause injuries to the intestinal epithelium, by the absorption and excretion of the pathogen thereby protecting the intestinal mucosa and improving the performance of the poultry (Trckova et al., 2009; Owen et al., 2012). Similar data in the previously published articles for improvement in broiler chickens' performance were shown upon supplementing diets with kaolin, bentonite, zeolite (Katouli et al., 2010), clay (Ani et al., 2014), and kaolin (Jorge de Lemos et al., 2015). Wu et al. (2013) showed that adding clinoptilolite to diets improved antioxidant capacity in broiler chickens as evidenced by increasing glutathione 
peroxidase, catalase, and total superoxide dismutase activities as well as decreasing malondialdehyde content of the liver. Adamis et al. (2005) discussed the adverse effect of using mineral silicate in the diet of poultry and livestock on their health, yield, and consumers. It is well established that the health and performance of birds are influenced by the nutrient and metabolites of blood. Therefore, the current study was designed to investigate the effects of different levels of Kaolin on the parameters of growth performance and health status of broiler chickens.

\section{MATERIALS AND METHODS}

\section{Ethical approval}

The present study was accepted by the animal ethics committee in Cairo University, Egypt, under the registration number (CU-I-F-49-18).

\section{Chickens management and experimental design}

A total of 240 unsexed one-day-old Avian 48 breed chickens were used in this experiment. The chickens were individually weighed and randomly allotted into 3 equal groups ( 80 chickens per each) and each group was subdivided into 4 replicates $(20$ chickens per each). The chicks were housed in a clean and well-ventilated room (side extraction systems, which removed air through the sides of the housing), previously disinfected with formalin (one part of formalin to 49 parts of water). The room was supplied with electric heaters to adapt to the environmental temperature according to the age of the chickens (Cobb-Vantress, 2008). Feeds and water were provided ad-libitum (using galvanized poultry feeder and inverted plastic drinker). Neomycin sulphate, clostin sulphate, spectinomycin, and cephadrin were used in the drinking water as prophylactic against the most common infectious diseases (Abeer et al., 2019)

The broiler chickens were randomly allotted into 3 groups; each group ( 80 chickens per group) received one of the three experimental diets $(0.0,0.5$, and kaolin $1.0 \%$ for groups 1,2 , and 3 , respectively) during the experimental period (6 weeks). A basal diet formulated to meet the requirements of broiler chickens as recommended by Cobb-Vantress (2008). According to AOAC (1990), different proportions of ingredients to meet the requirements at different production periods and chemical analysis of the basal diets are presented in Table1.

\section{Measurements}

Body weight development, body weight gains, and feed intake of broiler chickens in different groups were weekly recorded. Feed Conversion Ratio (FCR), Protein Efficiency Ratio (PER), Efficiency of Energy Utilization (EEU) and Performance Index (PI) were calculated according to Crampton and Loyd (1959), Lambert et al. (1936), McDonald et al. (1987) and North (1981) respectively.

\section{Concentrations of blood serum lipids}

These parameters included serum total lipids, total cholesterol, serum high-density lipoprotein (HDL-cholesterol), serum low-density lipoprotein (LDL-cholesterol), and serum triglyceride. These parameters were respectively estimated according to Sidney and Barnard (1973), Allain et al. (1974), Lopes-Virella et al. (1977), and Assmann et al. (1984) using commercial kits produced by Biodiagnostic (Diagnostic and Research reagents). Serum VLDL-cholesterol was calculated by subtraction according to the following equation: VLDL-cholesterol: Total cholesterol - (HDL-cholesterol + LDL-cholesterol).

\section{Antioxidant enzymes}

These included serum Catalase (CAT), Superoxide dismutases (SODs), Glutathione peroxide (GPx) and lipid peroxidase (Malondialdehyde MDA). These antioxidant enzymes' activities were estimated according to Aebi (1984), Nishikimi et al. (1972), Paglia and Valentine (1967), and Satoh (1978) using commercial kits produced by Biodiagnostic (Diagnostic and Research reagents).

\section{Evaluation of the immune response}

The immune response of the chickens was estimated by lysosome activity and bactericidal activity.

\section{Lysosome activity}

Serum lysosome activity was measured with the turbid metric method described by Engstad et al. (1992); using 0.2 $\mathrm{mg} / \mathrm{ml}$ lyophilized Micrococcus lysodekticus as the substrate in phosphate buffer adjusted to $\mathrm{pH}$ 5.75. Fifty microliters of serum were added to $3 \mathrm{ml}$ of the bacterial suspension. The $540 \mathrm{~nm}$ absorbance was measured by spectrophotometer after-mixture (Ao) and after incubation at $37^{\circ} \mathrm{C}$ (A) for 30 minutes. The result expressed as one unit of lysosome activity was defined as a reduction in the absorbency of 0.001/min. (Lysosome activity, (A0-A)/A). 


\section{Bactericidal activity}

Serum bactericidal activity was determined by using $300 \mu$ of Aeromonas hydrophila suspension $\left(1.5 \times 10^{3}\right.$ cells $/ \mathrm{ml}$ ), and $300 \mu \mathrm{l}$ of fresh serum was mixed in sterile tubes according to Rainger and Rowley (1993). A blank consisted of $300 \mu 1$ of bacterial suspension and $300 \mu \mathrm{l}$ of sterile Phosphate Buffer Solution. The tubes were incubated at $28{ }^{\circ} \mathrm{C}$. Fifty $\mu \mathrm{l}$ of the sample was removed at $0,1 \mathrm{~h}, 2 \mathrm{~h}, 3 \mathrm{~h}$, and $4 \mathrm{~h}$, and different dilutions were plated on nutrient agar for $24 \mathrm{~h}$ at $28^{\circ} \mathrm{C}$, and then Colony Forming Units (CFU) were counted. The results were calculated as survival index (SI) (Wardlaw and Unkles, 1978). Values were calculated as follows: SI: CFU at the end / CFU at the start x100.

\section{Fourier transform infrared spectroscopy techniques}

It was one of the analytical techniques that had been previously used to gather information on the composition and crystallinity of the bone mineral (Fook and Guastaldi, 2005; Petra et al., 2005; Fuchs et al., 2008; Nagy et al., 2008). Collected bone samples were prepared in accordance with Greene et al. (2004). The sample was grounded to a fine powder with an agate mortar and pestle. Fourier Transform Infrared Spectroscopy (FTIR) grade potassium bromide (97-99 $\mathrm{mg}$ ) was ground to a fine powder in a separate agate mortar and pestle. The two powders (100 $\mathrm{mg}$ total) were then combined and mixed with a spatula. An additional $100 \mathrm{mg}$ of potassium bromide $(\mathrm{KBr})$ was ground into a fine powder, and then it was used to obtain background spectra. The sample was transferred into a sample cup for overflowing, and a coverslip was dragged across the top of the cup to remove excess powder and smoothed the sample surface to maintain uniform distribution of particle size. Each sample was then mixed with $\mathrm{KBr}$ and placed in a Diffuse Reflectance Fourier Transform Infrared Spectroscopy Techniques cell. Absorbance infrared spectra were obtained between $4000 \mathrm{~cm}-1$ and $400 \mathrm{~cm}-1$ wave number. This method of analysis gives information on the composition and crystallinity of the bone mineral, and at the same time indicates the behavior of the protein materials in bones.

\section{Statistical analysis}

Obtained data were subjected to one-way ANOVA to study the effect of different treatments on the different studied variables (body weight, feed utilization parameters, serum lipids, oxidative index and antioxidant enzymes and immune response items) using Statistical Analysis System (SAS, 1996) to assess significant differences using Honestly Significant Difference (HSD) $t$ test. The obtained data were presented as mean \pm standard error of mean (SE) and significance was considered at $\mathrm{P}<0.05$.

Table 1. Ingredient and chemical composition of the basal diets used for broiler chickens feeding during different experimental periods.

\begin{tabular}{|c|c|c|c|c|c|c|c|}
\hline \multirow[b]{2}{*}{ Ingredients } & \multicolumn{3}{|c|}{ Feed Type } & & \multicolumn{3}{|c|}{ Feed Type } \\
\hline & $\begin{array}{c}\text { Starter } \\
\text { diet }\end{array}$ & $\begin{array}{c}\text { Grower } \\
\text { diet }\end{array}$ & $\begin{array}{c}\text { Starter } \\
\text { diet }\end{array}$ & & $\begin{array}{c}\text { Starter } \\
\text { diet }\end{array}$ & $\begin{array}{c}\text { Grower } \\
\text { diet }\end{array}$ & $\begin{array}{c}\text { Starter } \\
\text { diet }\end{array}$ \\
\hline \multicolumn{4}{|c|}{ Ingredient (kg/ton) } & & \multicolumn{3}{|c|}{ Chemical composition\% } \\
\hline Yellow corn & 580 & 647 & 675 & Crude protein & 23.0 & 21.0 & 19.0 \\
\hline Corn gluten $(60 \%)$ & 18.5 & 31.5 & 15.5 & $\mathrm{ME}(\mathrm{Kcal} / \mathrm{kg}$ diet $)$ & 3010 & 3100 & 3200 \\
\hline Soybean meal (44\%) & 348 & 272 & 248 & Calcium & 1.0 & 0.9 & 0.85 \\
\hline Limestone & 2.5 & 18 & 17 & Available phosphors & 0.5 & 0.45 & 0.42 \\
\hline Mono calcium phosphate & 11.5 & 9.5 & 8.3 & Crude fiber & 2.3 & 2.4 & 2.4 \\
\hline Vegetable oil $^{1}$ & 5 & 5 & 20 & Ether extract & 2.6 & 2.8 & 2.9 \\
\hline Premix $^{2}$ & 3 & 3 & 3 & Chloride & 0.2 & 0.18 & 0.19 \\
\hline Lysine $^{3}$ & 2.5 & 3.6 & 2.5 & Sodium & 0.16 & 0.16 & 0.16 \\
\hline DL-Methionine $^{4}$ & 2.3 & 2.4 & 2.3 & Lysine & 1.4 & 1.3 & 1.1 \\
\hline Salt & 2.5 & 2.5 & 2.5 & Methionine & 0.62 & 0.62 & 0.56 \\
\hline Sodium bicarbonate & 2 & 2 & 2 & & & & \\
\hline Mycotoxin binder & 0.5 & 0.5 & 0.5 & & & & \\
\hline Phytase enzyme & 0.1 & 0.1 & 0.1 & & & & \\
\hline Enzyme mixture & 0.5 & 0.5 & 0.5 & & & & \\
\hline De-cocox & 0.5 & 0.5 & 0.5 & & & & \\
\hline Lincomix & 0.1 & 0.1 & 0.1 & & & & \\
\hline
\end{tabular}

${ }^{1}$ Vegetable oil (mixture of sunflower oil and cottonseed oil). ${ }^{2}$ The premix used was Heromix produced by Heropharm and composed of (per $\left.1.5 \mathrm{~kg}\right)$ vitamin A $12000000 \mathrm{IU}$, vitamin D3 $2500000 \mathrm{IU}$, vitamin E $10000 \mathrm{mg}$, vitamin K3 $2000 \mathrm{mg}$, thiamin $1000 \mathrm{mg}$, riboflavin $5000 \mathrm{mg}$, pyridoxine 1500 $\mathrm{mg}$, cyanocobalamine $10 \mathrm{mg}$, niacin $30000 \mathrm{mg}$, biotin $50 \mathrm{mg}$, folic acid $1000 \mathrm{mg}$, pantothenic acid. ${ }^{3} \mathrm{Lysine}$ : lysine hydrochloride (contain $98.5 \%$ Lysine). ${ }^{4}$ DL-Methionine (Produced by Evonic Company and contains $99.5 \%$ methionine).

\section{RESULTS}

\section{Growth performance}

As shown in Table 2 , the addition of 0.5 or $1.0 \%$ kaolin in the broiler chicken diet increased non-significantly $(\mathrm{P} \geq$ 0.05) final body weight and total gain by $4.5 \%$ and $4.7 \%$ and $4.4 \%$ and $4.5 \%$, respectively compared with the control group. On the other hand, it was found that kaolin addition at 0.5 or $1.0 \%$ decreased TFI by $1.0 \%$ and $1.8 \%$ and 
significantly $(\mathrm{P}<0.05)$ improved average FCR and EEU consequently throughout the whole experimental period by $(5.4 \%$ and $5.4 \%)$ and $(5.9 \%$ and $6.2 \%)$ respectively compared to the control group, while non-significantly (P $\geq 0.05)$ improved average protein efficiency ratio (PER) and performance index (PI) compared to the control group.

\section{Blood serum lipid profile}

The effect of kaolin addition in broilers' diet on serum lipid profile is presented in Table 3. It was observed that kaolin supplementation at the dose of 5 or $10 \mathrm{~g} / \mathrm{kg}$ in the diet non-significantly $(\mathrm{P} \geq 0.05)$ increased blood serum total lipids and triglycerides concentrations by $0.8 \%-0.25 \%$ and $5.9 \%-1.6 \%$, respectively, compared to the control group. On the other hand, kaolin supplementation at the dose of 5 or $10 \mathrm{~g} / \mathrm{kg}$ in the diet significantly $(\mathrm{P}<0.05)$ increased serum HDL concentration, while had no clear effect on serum cholesterol (CHO), LDL, and VLDL concentrations compared to the control group.

\section{Oxidative index and antioxidant enzymes activities}

The data of serum and liver oxidative marker and antioxidant enzyme activities are presented in tables 4 and 5 , respectively. Kaolin addition at the dose of $5 \mathrm{~g} / \mathrm{kg}$ in the broilers' diet significantly $(\mathrm{P}<0.05)$ reduced nitric oxide concentration in blood serum and liver tissues while higher inclusion level non-significantly $(\mathrm{P} \geq 0.05)$ reduced nitric oxide concentration compared to the control group. Moreover, both inclusion levels (5 or $10 \mathrm{~g} / \mathrm{Kg}$ diet) of kaolin nonsignificantly $(\mathrm{P} \geq 0.05)$ reduced the activity of $\mathrm{MDA}$ in blood serum and liver tissues, compared to the control group. Regarding antioxidant enzyme activities, it was observed that kaolin addition at the concentrations of $5 \mathrm{or} 10 \mathrm{~g} / \mathrm{kg}$ in the broiler chickens diet increased the activities of GPx, SOD, and CAT in both serum and liver tissues, compared to the control group. Moreover, kaolin addition at $10 \mathrm{~g} / \mathrm{kg}$ was more effective on serum antioxidant enzyme activities, compared to a lower kaolin addition.

\section{Immune response}

As shown in Table 6, kaolin addition at the concentration of 0.5 or $1.0 \%$ in the broiler chickens' diet nonsignificantly $(\mathrm{P} \geq 0.05)$ improved bactericidal and lysosome activities by $3.9-39.3 \%$ and $5.4-14.3 \%$, respectively, compared to the control group.

\section{Fourier Transform Infrared Spectroscopy}

Data about the FTIR spectra of all samples are recorded in Figure 1. All spectra of samples differed from the control sample and provide information regarding the effect of feed additives on the investigated bones.

The results of FTIR indicated a similarity in groups fed on the basal diet supplemented by $10 \mathrm{~g} \mathrm{kaolin} / \mathrm{kg}$ diet, compared to the control group. The results showed that mineralization and silicification started in the bone of the broiler chicken group fed on the basal diet with $5 \mathrm{~g}$ kaolin $/ \mathrm{kg}$ diet.

Table 2. Effects of different dietary kaolin supplementation on the growth performance and feed efficiency parameters of broiler chickens

\begin{tabular}{|c|c|c|c|}
\hline \multirow{2}{*}{ Parameters } & \multicolumn{3}{|c|}{ Dietary kaolin supplementation } \\
\hline & Control $(0.0 \%)$ & $0.5 \%$ & $1.0 \%$ \\
\hline Initial weight (g/chicken) & $40.55 \pm 0.23^{\mathrm{a}}$ & $40.38 \pm 0.25^{\mathrm{a}}$ & $40.43 \pm 0.27^{\mathrm{a}}$ \\
\hline Final weight (g/chicken) & $1864.47 \pm 35.95^{\mathrm{a}}$ & $1949.23 \pm 36.99^{\mathrm{a}}$ & $1946.76 \pm 37.65^{\mathrm{a}}$ \\
\hline Total gain (g/chicken) & $1824.05 \pm 35.88^{\mathrm{a}}$ & $1908.90 \pm 36.83^{\mathrm{a}}$ & $1906.54 \pm 37.49^{\mathrm{a}}$ \\
\hline Total feed intake (TFI g/chicken) & 3625.00 & 3587.5 & 3560.00 \\
\hline Average $\mathrm{FCR}^{1}$ & $2.02 \pm 0.05^{\mathrm{a}}$ & $1.91 \pm 0.04^{\mathrm{b}}$ & $1.90 \pm 0.04^{\mathrm{b}}$ \\
\hline Average PER $^{2}$ & $2.46 \pm 0.05^{\mathrm{a}}$ & $2.60 \pm 0.05^{\mathrm{a}}$ & $2.61 \pm 0.05^{\mathrm{a}}$ \\
\hline Average EEU ${ }^{3}$ & $6.25 \pm 0.16^{\mathrm{a}}$ & $5.91 \pm 0.13^{\mathrm{b}}$ & $5.86 \pm 0.13^{\mathrm{b}}$ \\
\hline Average $\mathrm{PI}^{4}$ & $95.24 \pm 3.36^{\mathrm{a}}$ & $105.17 \pm 3.78^{\mathrm{a}}$ & $105.69 \pm 3.99^{\mathrm{a}}$ \\
\hline
\end{tabular}

Values are means \pm standard error. Means within the same row of different litters are significantly different at $\mathrm{P} \leq 0.05$. Average FCR ${ }^{1}$ : Average feed conversion ratio. Average $\mathrm{PER}^{2}$ : average protein efficiency ratio. Average EEU ${ }^{3}$ : average efficiency of energy utilization. Average $\mathrm{PI}^{4}$ : average performance index.

Table 3. Effects of different dietary kaolin supplementation on serum lipids profile of broiler chickens

\begin{tabular}{|c|c|c|c|}
\hline \multirow{2}{*}{ Parameters } & \multicolumn{3}{|c|}{ Dietary kaolin supplementation } \\
\hline & Control (0.0\%) & $0.5 \%$ & $1.0 \%$ \\
\hline Total lipids (mg/dl) & $901.97 \pm 26.88^{\mathrm{a}}$ & $909.47 \pm 3.53^{\mathrm{a}}$ & $955.55 \pm 5.72^{\mathrm{a}}$ \\
\hline Triglycerides (mg/dl) & $218.59 \pm 2.88^{\mathrm{a}}$ & $219.13 \pm 4.31^{\mathrm{a}}$ & $222.19 \pm 4.25^{\mathrm{a}}$ \\
\hline $\mathrm{CHO}(\mathrm{mg} / \mathrm{dl})^{1}$ & $195.28 \pm 2.43^{\mathrm{a}}$ & $194.03 \pm 0.92^{\mathrm{a}}$ & $194.78 \pm 1.71^{\mathrm{a}}$ \\
\hline $\mathrm{HDL}(\mathrm{mg} / \mathrm{dl})^{2}$ & $51.22 \pm 1.61^{\mathrm{b}}$ & $54.33 \pm 1.56^{\mathrm{a}}$ & $55.43 \pm 2.21^{\mathrm{a}}$ \\
\hline $\operatorname{LDL}(\mathrm{mg} / \mathrm{dl})^{3}$ & $100.34 \pm 1.94^{\mathrm{a}}$ & $96.47 \pm 1.75^{\mathrm{a}}$ & $94.91 \pm 1.68^{\mathrm{a}}$ \\
\hline $\operatorname{VLDL}(\mathrm{mg} / \mathrm{dl})^{4}$ & $43.72 \pm 0.58^{\mathrm{a}}$ & $43.23 \pm 0.86^{\mathrm{a}}$ & $44.45 \pm 0.84^{\mathrm{a}}$ \\
\hline
\end{tabular}

Values are means \pm standard error. Means within the same row of different litters are significantly different at $\mathrm{P} \leq 0.05$. $\mathrm{CHO}^{1}$ : total cholesterol. HDL ${ }^{2}$ : high-density lipoprotein, $\mathrm{LDL}^{3}$ : low-density lipoprotein. $\mathrm{VLDL}^{4}=$ very low-density lipoprotein. 
Table 4. Effects of different dietary kaolin supplementation on some serum and liver tissue oxidative index activities of broiler chickens

\begin{tabular}{|c|c|c|c|}
\hline \multirow{2}{*}{ Parameters } & \multicolumn{3}{|c|}{ Dietary kaolin supplementation } \\
\hline & Control $(0.0 \%)$ & $0.5 \%$ & $1.0 \%$ \\
\hline \multicolumn{4}{|l|}{ Blood serum } \\
\hline Nitric oxide (umol/L) & $55.58 \pm 0.71^{\mathrm{a}}$ & $50.74 \pm 0.27^{\mathrm{b}}$ & $54.89 \pm 0.62^{\mathrm{a}}$ \\
\hline $\operatorname{MDA}(\mathrm{nmol} / \mathrm{ml})^{*}$ & $11.76 \pm 0.69^{\mathrm{a}}$ & $10.89 \pm 0.48^{\mathrm{a}}$ & $10.65 \pm 1.15^{\mathrm{a}}$ \\
\hline \multicolumn{4}{|l|}{ Liver tissues } \\
\hline Nitric oxide (umol/g) & $50.58 \pm 0.32^{\mathrm{a}}$ & $46.55 \pm 0.40^{\mathrm{b}}$ & $49.69 \pm 1.03^{\mathrm{ab}}$ \\
\hline $\mathrm{MDA}(\mathrm{nmol} / \mathrm{g})$ & $10.12 \pm 0.60^{\mathrm{a}}$ & $9.76 \pm 0.65^{\mathrm{a}}$ & $9.75 \pm 0.40^{\mathrm{a}}$ \\
\hline
\end{tabular}

Values are means \pm standard error. Means within the same row of different litters are significantly different at P $\leq 0.05$. $*$ MDA: Lipid peroxide (Malondialdehyde)

Table 5. The effects of different dietary kaolin supplementation on some serum and liver tissue antioxidant enzyme activities of broiler chickens.

\begin{tabular}{|c|c|c|c|}
\hline \multirow{2}{*}{ Parameters } & \multicolumn{3}{|c|}{ Dietary kaolin supplementation } \\
\hline & Control (0.0\%) & $0.5 \%$ & $1.0 \%$ \\
\hline \multicolumn{4}{|l|}{ Blood serum } \\
\hline $\mathrm{GPx}(\mathrm{mu} / \mathrm{ml})^{1}$ & $35.69 \pm 0.57^{\mathrm{b}}$ & $38.47 \pm 0.35^{\mathrm{a}}$ & $38.35 \pm 0.87^{\mathrm{a}}$ \\
\hline $\operatorname{SOD}(\mathrm{U} / \mathrm{ml})^{2}$ & $282.82 \pm 50.06^{\mathrm{a}}$ & $320.30 \pm 27.17^{\mathrm{a}}$ & $320.51 \pm 25.64^{\mathrm{a}}$ \\
\hline $\operatorname{CAT}(\mathrm{U} / \mathrm{L})^{3}$ & $26.45 \pm 8.96^{\mathrm{b}}$ & $38.79 \pm 0.64^{\mathrm{b}}$ & $56.85 \pm 4.34^{\mathrm{a}}$ \\
\hline \multicolumn{4}{|l|}{ Liver tissues } \\
\hline GPx (U/g) & $38.90 \pm 10.71^{\mathrm{a}}$ & $43.86 \pm 2.48^{\mathrm{a}}$ & $44.60 \pm 7.08^{\mathrm{a}}$ \\
\hline SOD (U/g) & $282.17 \pm 24.22^{\mathrm{a}}$ & $354.33 \pm 62.07^{\mathrm{a}}$ & $331.03 \pm 63.25^{\mathrm{a}}$ \\
\hline CAT (U/g) & $0.13 \pm 0.01^{\mathrm{a}}$ & $0.16 \pm 0.02^{\mathrm{a}}$ & $0.15 \pm 0.01^{\mathrm{a}}$ \\
\hline
\end{tabular}

Values are means \pm standard error. Means within the same row of different litters are significantly different at $\mathrm{P} \leq 0.05$. GPx ${ }^{1}$ : Glutathione peroxide. SOD $^{2}$ : Superoxide dismutases. CAT $^{3}$ : Catalase.

Table 6. The effects of different dietary kaolin supplementation on bactericidal and lysosome activity of broiler chickens.

\begin{tabular}{|c|c|c|c|}
\hline \multirow{2}{*}{ Parameters } & \multicolumn{3}{|c|}{ Dietary kaolin supplementation } \\
\hline & Control $(0.0 \%)$ & $0.5 \%$ & $1.0 \%$ \\
\hline Bactericidal activity (survival index $\%$ ) & $32.07 \pm 2.18^{\mathrm{a}}$ & $30.79 \pm 2.43^{\mathrm{a}}$ & $30.33 \pm 2.58^{\mathrm{a}}$ \\
\hline $\mathrm{RTC}^{*}$ & 100 & 96.01 & 94.6 \\
\hline Lysosome (unit/ml) & $0.28 \pm 0.02^{\mathrm{a}}$ & $0.39 \pm 0.03 \mathrm{a}$ & $0.32 \pm 0.02^{\mathrm{a}}$ \\
\hline $\mathrm{RTC}^{*}$ & 100 & 139.3 & 114.3 \\
\hline
\end{tabular}

Values are means \pm standard error. Means within the same row of different litters are significantly different at $(\mathrm{P} \leq 0.05)$. RTC*: Relative to control.

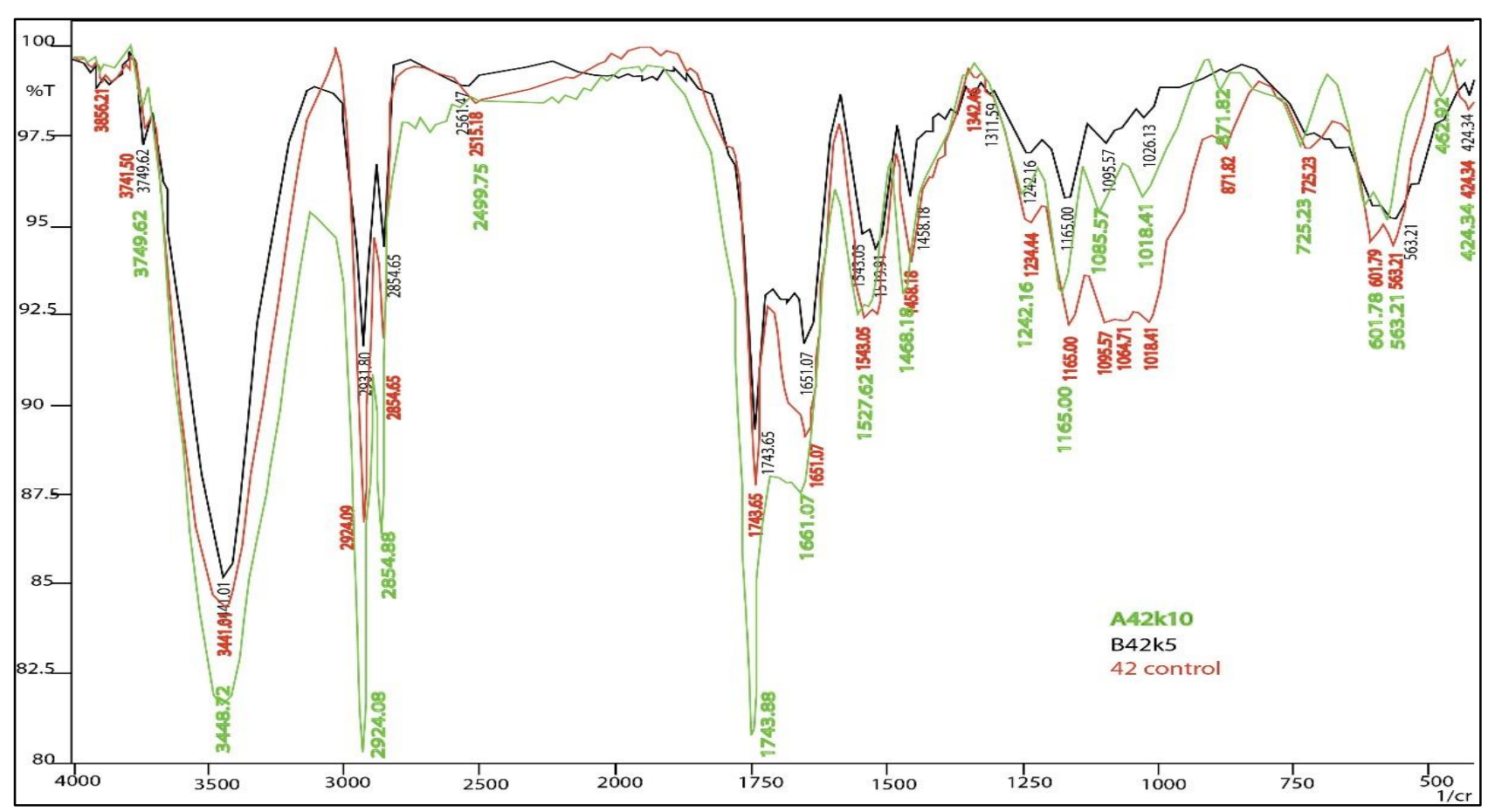

Figure 1. Fourier Transform Infrared Spectroscopy (FTIR) showing the difference between the control and the groups fed with $5 \mathrm{~kg}$ and $10 \mathrm{~kg}$ of kaolin/ton of the diet. Red line represents FTIR result of FTIR for the control group which had no additions in the diet, Black line represents the result of FTIR for the group B which took $5 \mathrm{~kg}$ of kaolin per ton of ration, and green one represents the result of FTIR for the group A which took $10 \mathrm{~kg}$ of kaolin per ton of ration. samples were taken at age of the 42 days. 
Generally, the growth performance and feed utilization parameters were considered an important index in poultry studies. It has been reported that dietary supplementation with kaolin improved enzymatic activity of the gastrointestinal secretion (Ouhida et al., 2000; Alzueta et al., 2002). The improvement of growth performance and better feed efficiency parameters of broiler chickens' groups fed with kaolin-containing diets may be related to enhancing nutrients digestibility and absorption through increasing enzyme secretion and intestinal health. Moreover, it was found that kaolin at both concentrations in broiler chickens' diets significantly reduced feed intake, compared to the control group, which may be related to the high reduction of digest transit rate and improvement of digestion (Angulo et al., 1995). Results of previous experiments on the effects of clay on broiler performance were generally inconsistent (Ouhida et al., 2000). The feeding values of clays are known to be affected by the kind of clays, producing area, grade, and their physicochemical and structural characteristics. The present study agreed with the findings of Xia et al. (2004), Parizadian et al. (2013), and Jorge de Lemos et al. (2015).

The obtained results of serum lipid profile were in the normal range and the results of the present study were in agreement with previous findings (Miles and Henry, 2007; Safaeikatouli et al., 2011; Emam et al., 2019). Numerical reduction of serum cholesterol in broiler chickens gave kaolin in the diet is consistent with the specific inhibition of hepatic cholesterol biosynthesis (Kato et al., 1969).

Nitric oxide (NO) is a poisonous, unstable free radical gas that has been known for years to be a constituent of air pollutant and is involved in the depletion of the ozone layer. However, nitric oxide is produced by all types of body cells (Mayer and Hemmens, 1997) and is considered the most important molecule for blood vessel health and neuronal communication (Schmidt and Walter, 1994). On the other hand, when it is produced in large excess or produced with reactive oxygen species (ROS) con-currently, Nitric oxide (NO) also displays neurotoxicity and it can induce apoptotic cell death in different types of neuronal cells. Lower NO in serum or liver tissues of the broiler chicken fed on kaolin supplemented ration indicated that the zeolites show the ability to bind NO, 4-hydroxy-noneal, and oxygen which may also have an antioxidative effect (Šverko et al., 2004). The present data were in agreement with Wu et al. (2013) stating that the activity of total nitric oxide synthase was significantly $(\mathrm{P}<0.05)$ decreased in $2 \%$ natural clinoptilolite, and it modified the clinoptilolite group than the control group.

Free radicals can generate ROS in cells. It can contribute to cell and tissue damage in the living body. The ability of a cell to keep functional homeostasis depends on the fast induction of protective antioxidant enzymes. The antioxidants may prevent these damages induced by oxidation of protein and lipid. The antioxidant enzymes include GPx, SOD, and CAT. These are the three main antioxidant enzymes in the body, which remove unwanted $\cdot{ }^{\circ} 2-$, $\mathrm{ROOH}$, hydrogen peroxide (H2O2), and the ones produced by free radicals. The concentrations of SOD, CAT, or GPx play an important role in protecting cells against the oxidative stress (Ermak and Davies, 2002). Decreased activity of these enzymes will induce increased free radicals and then will lead to damage of the corresponding tissue. Malondialdehyde (MDA) is an ending product of lipid peroxidation, so the amounts of MDA could be used to assess the extent of lipid peroxidation (Satoshi et al., 1989). The higher activities of GPx, SOD, and CAT and reduced activity of MDA in serum or liver tissues of the broiler chickens fed on the diets supplemented by 5 or $10 \mathrm{~kg}$ kaolin/ton, compared with the control group, were supported by $\mathrm{Wu}$ et al. (2013) stating that the activities of liver GSH-Px, CAT, and T-SOD were increased in the broiler chickens fed with $2 \%$ natural clinoptilolite group and modified clinoptilolite group.

Lysosome activity is an effective tool in attacking the cell wall polysaccharide of different bacterial species (Manchenko, 1994), leading to a breakdown and hydrolyze a tetrasaccharide found most often in the cell wall of Grampositive bacteria. Moreover, improvement of lysosomal and bactericidal activity of broiler chickens' serum as a result of dietary kaolin addition did not significantly increase the immune stimulation, compared to the control group. The obtained data were in harmony with Harikrishnan et al. (2018), suggesting that $C$. idellus fed with kaolin enriched diet improved lysosome activity, compared to the control group. The Organic compound phase included the OH group, C-H group, and protein group with specific range and it was described as follows: The $\mathrm{OH}$ group represented by the band at $3441.01 \mathrm{~cm}^{-1}$ in the control sample was assigned to the abroad band which represents $(\mathrm{OH})$ hydroxyl stretching due to intermolecular hydrogen bonding of the hydroxyl group. The results indicated that these groups were shifted in some conditions. In some samples, $\mathrm{OH}$ groups increased in comparison to the control sample and decreased in others. As noticed in the bone sample of the group with $10 \mathrm{~kg}$ kaolin as a feed additive was shifted to increase in comparison to the control group at $3448.72 \mathrm{~cm}^{-1}$. The C-H group recorded at the band with $2924.09 \mathrm{~cm}^{-1}$ was assigned to C-H stretching in

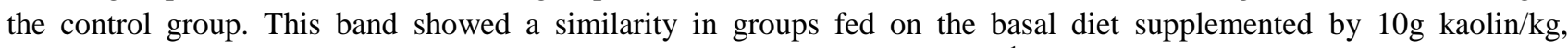
compared to the control group, while increased in groups B to $2931.80 \mathrm{~cm}^{-1}$ in comparison to the control group. The protein bands between $3421.1 \mathrm{~cm}^{-1}$ and $2925.48 \mathrm{~cm}^{-1}$ in group samples are protein characteristic and the increase and decrease of this band indicated the expansion or contraction of the protein area (Abdel Maksoud, 2010).

\section{CONCLUSION}

It can be concluded that supplementation of $0.5 \%$ or $1.0 \%$ of kaolin in broiler chickens' diet non-significantly improved growth performance, feed efficiency parameters, and bone mineralization and had no adverse effect on the serum lipid 
profile. Moreover, kaolin addition had a beneficial effect on antioxidant activity and immune response of broiler chicken, however, $0.5 \%$ of kaolin was more effective than higher concentration levels. Kaolinite has a low cation exchange capacity which easily adsorbs water. The result of Fourier Transform Infrared Spectroscopy indicates a similarity in the groups fed on the basal diet supplemented by $10 \mathrm{~g}$ kaolin $/ \mathrm{kg}$ diet in comparison with the control group. The results show the start of mineralization and silicification in the bone.

\section{DECLARATION}

\section{Competing interests}

The authors declare that they have no known competing interests or personal relationships that could have appeared to influence the obtained results of this paper.

\section{Acknowledgments}

The authors would like to thank the Geology department, Faculty of Science, Cairo University, Egypt for their support. This research did not receive any specific grant from funding agencies in the public, commercial, or not-forprofit sectors.

\section{REFERENCES}

Abdel Maksoud G (2010). Comparison between the properties of "accelerated-aged" bones and archaeological bones. Mediterranean Archaeology and Archaeometry, 10(1): 89-112. Available at: http://maajournal.com/Issues/2010/Vol10-1/Maksoud\%2010_1.pdf.

Abeer, EMM, Ali B, Naena GI, and Salim AA (2019). Effect of Some Antibiotic Alternatives on Experimentally Escherichia Coli Infected Broiler Chicks. Alexandria Journal of Veterinary Sciences, 63(1): 110-125. DOI: https://www.doi.org/10.5455/ajvs.66926

Adamis Z, Fodor J, and Williams RB (2005). Bentonite, Kaolin and Selected Clay Minerals. World Health Organization, Geneva, Switzerland. (LC/NLM classification: QV 65), p. 196. Available at: https://www.who.int/ipcs/publications/ehc/ehc_231.pdf

Aebi H (1984). Catalase in vitro. Methods Enzymology, 105: 121-126. DOI: https://doi.org/10.1016/S0076-6879(84)05016-3

Allain CC, Poon LS, Chan CS, Richmond W, and Fu PC (1974). Enzymatic determination of total serum cholesterol. Clinical Chemistry Journal, 20(4): 470-475. PMID: 4818200.

Alzueta C, Ortiz LT, Rebole A, Rodriguez ML, Centreno C, and Trevino J (2002). Effects of remoral of mucilage and enzyme of sepiolite supplement on the nutrient digestibility and metabolizable energy of a diet containing linseed in broiler chickens. Animal Feed Science Technology, 97: 169181. DOI: https://www.doi.org/10.1016/S0377-8401(02)00030-5.

Angulo E, Brufau J, and Estere-Garcia E (1995). Effect of sepiolite pellet durability in feed differing in fat and fiber content. Animal Feed Science Technology, 53: 232-241. Available at: https://agris.fao.org/agris-search/search.do?recordID=NL19960023583

Ani AO, Ogbu CC, and Iloh EA (2014). Response of broiler chicks to diets containing graded levels of clay. Journal of Animal and Plant Sciences, 24: 30-34. Available at: https://www.researchgate.net/publication/281440801

AOAC (1990). Official methods of analysis. Association of Official Analytical Chemists. 14th. Ed. Washington, D.C. Available at: https://law.resource.org/pub/us/cfr/ibr/002/aoac.methods.1.1990.pdf.

Assmann G, Schulte H, and von Eckardstein A (1984). Hypertriglyceridemia and elevated levels of lipoprotein (a) are risk factors for major coronary events in middle-aged men. American Journal of Cardiology, 77: 1179-1184. DOI: https://www.doi.org/10.1016/s0002-9149(96)00159-2.

Bernard JH, and Rost R (1992). Encyclopaedic knowledge of minerals. Czech. 1st ed. Academia, Prague, p. 704. Available at: https://katalog.kfbz.cz/records/1d1b34ad-a6a7-4b6b-ac1a-e033977a0ad2?locale=en

Castanon JI (2007). History of the use of antibiotic as growth promoters in European poultry feeds. Poultry Science, 86: 2466-2471. DOI: https://doi.org/10.3382/ps.2007-00249.

Cobb-Vantress (2008). Manual de manejo de frangos de corte COBB. Guapiaçu: Cobb-Vantress Brasil, Pp. 19-24. Available at: https://wp.ufpel.edu.br/avicultura/files/2012/04/Cobb-Manual-Frango-Corte-BR.pdf

Crampton EW, and Loyd LE (1959). Fundamentals of Nutrition, w. H. Freeman and company. San Francisco and London, p. 494. DOI: https://www.doi.org/10.1177\%2F146642406108100155.

Duda R, Rejl L, and Slivka D (1990). Minerals (in Czech). Aventinum, Prague, P. 519. Available at: https://www.mindat.org/loc-7944.html.

Emam KRS, Abdel-dayem AA, and Abd El-Galil K (2019). Effect of zeolite supplementation on productive performance and blood constituents of broiler chicken under drinking saline well water conditions. Egypt. Poultry Science, 39(1): 221-231. DOI: https://dx.doi.org/10.36380/scil.2019.wvj15.

Engstad RE, Robertsen B, and Frivold E (1992). Yeast glucan induces increase in activity of lysozyme and complement-mediated haemolytic activity in Atlantic salmon blood. Fish \& Shellfish Immunology, 2: 287-297. DOI: https://www.doi.org/10.1016/S1050-4648(06)80033-1.

Ermak G, and Davies KJ (2002). Calcium and oxidative stress: from cell signaling to cell death. Molecular Immunology, 38: 713-721. DOI: https://www.doi.org/10.1016/s0161-5890(01)00108-0.

Fook MVL, and Guastaldi AC (2005). Comparison of crystallinity between natural hydroxyapatite and synthetic cp-Ti /HA coatings, J. Materials Research, 8: 207-211. DOI: https://www.doi.org/10.1590/S1516-14392005000200022.

Fuchs RK, Allen MR, Ruppel ME, Diab T, Phipps RJ, Miller LM, and Burr DB (2008). In situ examination of the time-course for secondary mineralization of Haversian bone using synchrotron Fourier transform infrared microspectroscopy. Journal Matrix Biology, 27: 34-41. DOI: https://www.doi.org/10.1016/j.matbio.2007.07.006.

Ghosal S (1990). Chemistry of Shilajit, an immunomodulatory ayurvedic rasayan. Pure and Applied Chemistry, 62: 1285-1288. DOI: https://www.doi.org/10.1351/pac199062071285.

Greene EF, Touch S, Webb E, and Amarasiriwardena D (2004). Application of diffuse reflectance infrared fourier transform spectroscopy (Drifts) for the identifica- tion of potential digenesis and crystallinity changes in teeth. Microchemical Journal, 76: 141-149. DOI: https://www.doi.org/10.1016/j.microc.2003.11.006

Harikrishnan R, Jawahar S, Srikanthan C, Paray BA, Al-Sadoon MK, and Balasundaram C (2018). Kaolin incorporated diet on growth and immune response in Ctenopharyngodon idellus against Aeromonas hydrophila. Fish \& Shellfish Immunology, 77: 364-373. DOI: https://www.doi.org/10.1016/j.fsi.2018.04.015. 
Jorge de Lemos M, Calixto LFL, Alves ODS, Santos de Souza D, Moura BB, and Reis TL (2015). Kaolin in the diet and its effects of performance, litter moisture and intestinal morphology of broiler chickens. Ciência Rural, 45: 1835-1840. DOI: http://dx.doi.org/10.1590/0103$\underline{8478 \mathrm{cr} 20141193 .}$

Kato R, Onoda K, and Omori Y (1969). Effect of aflatoxin B1 on the incorporation of 14 C-acetate into cholesterol by rat liver. Experimentia, 25(10): 1026. DOI: https://www.doi.org/10.1007/BF01901402.

Katouli MS, Boldaji F, Dastar B, and Hassani S (2010). Effect of different levels of kaolin, bentonite and zeolite on broilers performance. Journal of Biological Sciences, 10: 58-62. DOI: https://dx.doi.org/10.3923/jbs.2010.58.62.

Lambert WV, Ellis NR, Block WH, and Titus HW (1936). The role of nutrition in genetics. The American Society of Animal Production, $29: 236$. Available at: http://jas.fass.org/cgi/reprint/1936b/1/236-a

Lopes-Virella MF, Stone P, Ellis S, and Coldwell AJ (1997). Cholesterol determinations in high density lipoproteins separated by three methods. Clinical Chemistry, 23: 882-884. Available at: https://pubmed.ncbi.nlm.nih.gov/192488/.

Manchenko GP (1994). Lysozyme. Handbook of Detection of Enzymes on Electrophoretic Gels,CRC Press, Boca Raton, Fla, p. 223. Available at: https://www.routledgehandbooks.com/doi/10.1201/9781420040531-4.

Mayer B, and Hemmens B (1997). Biosynthesis and action of nitric oxide in mammalian cells, Trends Biochemical Science, 22: 477-481. DOI: https://doi.org/10.1016/s0968-0004(97)01147-x.

McDonald P, Edwards RA, and Greenhelgh JFD (1987). Animal Nutrition text, English Language Book.Socity/Longman, p. 270. Available at: https://www.agriculture.gov.ie/media/migration/farmingsectors/organicfarming/publications/organic_poultry_report.pdf.

Miles RD, and Henry PR (2007). Safety of Improved Milbond-TX® when fed in broiler diets at greater than recommended levels. Animal Feed and Science Technology, 138: 309-317. DOI: https://doi.org/10.1016/j.anifeedsci.2007.04.008.

Moore DM, and Reynolds RC (1997). X-Ray Diffraction and Identification and Analysis of Clay Minerals. 2nd ed. New York: Oxford Univeristy. Press, 135(6): 819-842. DOI: https://www.doi.org/10.1017/S0016756898501501

Nagy G, Lorand T, Patonai Z, Montsko G, Najnoczky I, Marcsik A, and Mark L (2008). Analysis of pathological and non-pathological human skeletal remains by FT-IR spectroscopy, Forensic Science International, 175: 55-60. DOI: https://doi.org/10.1016/j.forsciint.2007.05.008.

Nishikimi M, Rao NA, and Yagi K (1972). The occurrence of superoxide anion in the reaction of reduced phenazine methosulfate and molecular oxygen. Biochemical and Biophysical Research Commun, 46: 849-854. DOI: https://doi.org/10.1016/S0006-291X(72)80218-3.

North MO (1981). Commercial chicken production, 3rd ed. AVI, Publishing company INC, USA, pp. 67-87. Available at: https://www.cabdirect.org/cabdirect/abstract/19840180814.

Ouhida IJ, Perez JF, Piedrafita J, and Gasa J (2000). The effects of sepiolite in the broiler chicken diets of high, medium and low viscosity, productive performance and nutritive value. Animal Feed Science Technology, 85: 183-194. DOI: https://doi.org/10.1016/S0377-8401(00)00148-6.

Owen OJ, Amakiri AO, and Ezeano CI (2010). The cost benefit analysis of incorporating bitter leaf (V. amygdalina) meal in broiler finishers diet. Journal of Environmental Issues and Agriculture in Developing Countries, 2(1): 131-141. Available at: https://www.researchgate.net/publication/263327307

Owen OJ, Nodu MB, Dike UA, and Ideozu HM (2012). The Effects of Dietary Kaolin (Clay) as Feed Additive on the Growth Performance of Broiler Chickens. Greener Journal of Agricultural Sciences, 2(6): 237-245. Available at https://gjournals.org/GJAS/archive/oct-2012-vol-26/owen-etal.html

Paglia DE, and Valentine WN (1967). Studies on the quantitative and qualitative characterization of erythrocyte glutathione peroxidase. Journal of Laboratory Clinical Medicine, 70: 158-169. DOI: https://doi.org/10.5555/uri:pii:0022214367900765.

Parizadian KV, Shams SM, Hassani S, and Mostafalo Y (2013). Effects of physical size of clinoptilolite on growth performance, serum biochemical parameters and litter quality of broiler chickens in the growing phase. Poultry Science Journal, 1: 93-104. Available at: https://www.psj.gau.ac.ir/article_1481_htm

Petra M, Anastassopoulou J, Theologis T, and Theophanides T (2005). Synchrotron micro-FT-IR spectroscopic evaluation of normal paediatric human bone, Journal Molecular Structure, 733: 101-110. Available at: https://www.journals.elsevier.com/journal-of-molecular-structure

Rainger G, and Rowley A (1993). Antibacterial activity in the serum and mucus of rainbow trout, Oncorhynchus mykiss, following immunization with Aeromonas salmonicida. Fish and shellfish Immunology, 3: 475-482. Available at: https://agris.fao.org/agrissearch/search.do?recordID=GB19960087509

Safaeikatouli M, Jafariahangari Y, and Baharlouei A (2011). An Evaluation on the Effects of Dietary Kaolin and Zeolite on Broilers Blood Parameters, T4, TSH and Growth Hormones. Pakistan Journal of Nutrition, 10(3): 233-237. DOI: https://dx.doi.org/10.3923/pjn.2011.233.237

SAS Institute (1996). SAS User's Guide: Statistics. SAS Institute, Inc., Cary, NC. Available at: https://support.sas.com/documentation/onlinedoc/91pdf/sasdoc_91/ets_ug_7314.pdf.

Satoh K (1978). Serum lipoperoxides in cerebrovascular disorders determined by colorimetric method. Clinical Chemistry Acta, 90: 37-43. DOI: https://doi.org/10.1016/0009-8981(78)90081-5.

Satoshi S, Kiyoji T, Hiroyo K, and Fumio N (1989). Exercise-induced lipid peroxidation and leakage of enzymes before and after vitamin E supplementation. International Journal Biochemical, 21: 835-838. DOI: https://doi.org/10.1016/0020-711X(89)90280-2

Schmidt HW, and Walter U (1994). NO at work, Cell, 78: 919-925. DOI: https://doi.org/10.1016/0092-8674(94)90267-4

Sidney PG, and Barnard R (1973). Improved manual spectrophotometric procedure for determination of serum triglycerides. Clinical Chemistry, 19(9): 1077-1078. Available at: https://pubmed.ncbi.nlm.nih.gov/4744812/.

Slivka V (2002). Mining and treatment of silicate.1st edition. Prague: Silikátový svaz, (Silicate Association), p. 443. Available at: https://www.worldcat.org/title/tezba-a-uprava-silikatovych-surovin/oclc/51189335

Šverko V, Sobočanec S, Balog T, Čolić M, and Marotti T (2004). Natural micronized clinoptilolite and clinoptilolite mixtures with 40\% Urtica dionica L. extract as possible antioxidants. Food Technology of Biotech, 42: 189-192. Available at: https://hrcak.srce.hr/110843.

Trckova M, Matlova L, Dvorska L, and Pavlik I (2004). Kaolin, bentonite, and zeolites as feed supplements for animals: health advantages and risks. Czech, pp. 389-399. Available at: http://www.vri.cz/docs/vetmed/49-10-389.pdf.

Trckova M, Vondruskova H, Zraly Z, Alexa P, Hamrik J, Kummer V, Maskova J, Mrlik V, Krizova K, Slana I et al. (2009). The effect of kaolin feeding on efficiency, health status and course of diarrhoeal infections caused by enterotoxigenic Escherichia coli strains in weaned piglets. Veterinarni Medicina, 54: 47-63. Available at: https://www.researchgate.net/publication/237410569.

Wardlaw A, and Unkles S (1978). Bacterial activity of Coelmic fluid from the sea urchin Echinus esculentus. Journal of Invertebrate Pathology, 32: 25-34. DOI: https://doi.org/10.1016/0022-2011(78)90170-2.

Wu Y, Wu Q, Zhou Y, Ahmad H, and Wang T (2013). Effects of clinoptilolite on growth performance and antioxidant status in broilers. Biological Trace Element Research, 155: 228-235. Available at: https://link.springer.com/article/10.1007/s12011-013-9777-6.

Xia MS, Hu CH, and Xu ZR (2004). Effects of copper-bearing montmorillonite on growth performance, digestive enzyme activities and intestinal micro-flora and morphology of male broilers. Poultry Science, 83: 1663-1875. DOI: https://doi.org/10.1093/ps/83.11.1868. 